\title{
Update on Herpes simplex keratitis management
}

\author{
Daniel Sibley $\mathbb{D}^{1} \cdot$ Daniel F. P. Larkin ${ }^{1,2,3}$
}

Received: 8 April 2020 / Revised: 14 July 2020 / Accepted: 14 August 2020 / Published online: 25 August 2020

(c) The Author(s), under exclusive licence to The Royal College of Ophthalmologists 2020

\begin{abstract}
Herpes simplex keratitis (HSK) is a common, potentially blinding condition characterised by recurrent infections of the cornea, seen by both general ophthalmologists and corneal specialists. Successful treatment of recurrences reduces disease duration, prevents progressive corneal scaring leading to vision loss and reduces risk of further recurrences. In this review we discuss the relative advantages of the diagnostic laboratory investigations including polymerase chain reaction, viral culture and fluorescence-based immunohistochemistry. We review treatment strategies in selected aspects of HSK and discuss the management options in cases not responding to treatment.
\end{abstract}

\section{Introduction}

Herpes simplex keratitis (HSK) is a potentially blinding condition characterised by recurrent infections of the cornea. It is predominantly caused by infection with herpes simplex virus type 1 (HSV-1) and to a lesser extent the HSV type 2 (HSV-2), large double stranded DNA viruses which are members of the human $\alpha$-herpesvirus ( $\alpha$-HHV) family.

Infection with herpes simplex is widespread; globally it is estimated $67 \%$ of the population aged $0-49$ years has been exposed to HSV 1 and $11.3 \%$ to HSV 2 [1, 2]. The incidence of HSK in developed countries is estimated to be between 10 and 30 per 100,000 of the population per year with a prevalence of 149 per 100,000 [3-5]. The incidence and prevalence are thought to be higher in developing countries where the prevalence of HSV 1 and 2 infections are higher, and affect a younger demographic, although there is a lack of surveillance-based epidemiologic studies in these populations. Currently no vaccine exists for either HSV 1 or 2 .

Primary HSV eye infection is contracted by direct contact via mucus membranes [6]. This is usually subclinical but can present as a transient unilateral blepharitis, follicular

Daniel F. P. Larkin

f.larkin@ucl.ac.uk

1 Cornea \& External Diseases Service, Moorfields Eye Hospital, 162 City Road, London EC1V 2PD, UK

2 NIHR Moorfields Clinical Research Facility, Moorfields Eye Hospital, London, UK

3 UCL Institute of Ophthalmology, London, UK conjunctivitis and occasional epithelial keratitis. The virus then remains latent in the ophthalmic division of the trigeminal ganglion with reactivation causing recurrent infection [7, 8]. Relapses are common with $40 \%$ of patients experiencing $2-5$ relapses in a lifetime and $11 \%$ experiencing 6-15 relapses [9].

Vision loss in HSK is seen in those with recurrent infection, in particular recurrent stromal keratitis. The Rochester epidemiology project reported on all cases seen over a 30-year period, and found an estimated $11 \%$ of patients with any history of HSK have a final VA below 20/ 200 [5]. Even in eyes that retain good vision, infection causes corneal opacities that can induce aberrations, irregular astigmatism and reduce the overall optical quality of the eye [10]. Bilateral disease is less common but often more severe, with a higher incidence of scarring and decreased visual acuity, usually related to other ocular and systemic co-morbidities such as atopy and immunodeficiency $[11,12]$. In addition to visual loss HSK also reduces the quality of life of patients even when quiescent [13]. In 2003 in the USA it was estimated treatment of HSK cost in excess of 17.7 million dollars annually, representing a significant burden on modern healthcare systems [14].

Despite its high prevalence HSK remains a disorder causing both diagnostic and treatment challenges. This review will discuss selected aspects of current practice and some points of uncertainty in the management of HSK.

\section{Laboratory diagnosis in keratitis}

Clinical diagnosis in acute keratitis is not usually difficult, epithelial disease characterised by a branching dendritic 
ulcer, the base of which stains with fluorescein and terminal bulbs (Fig. 1). Ulcers can enlarge, particularly in steroidtreated eyes, to have a geographic (amoeboid) shape (Fig. 2a, b). Although treatment is frequently commenced without laboratory diagnosis, confirmation of HSV should be attempted if an ulcer does not have a classic dendritic appearance, particularly if it is the first episode of recurrence without a prior confirmed diagnosis. Laboratory diagnosis is also of value in decision-making in corneas with a known history of HSK but in which a new epithelial defect does not have characteristic features. In addition to the beneficial effect of debridement of an epithelial lesion, obtaining a corneal swab or scraping for laboratory investigation is helpful for exclusion of conditions that require alternative treatment regimens such as varicella-zoster virus $[15,16]$, cytomegalovirus [17], Epstein-Barr virus [18] and human herpesvirus-6 [19]. The diagnosis of acanthamoeba epithelial keratitis should always be excluded in contact lens wearers, not least as treatment delay caused by initial misdiagnosis as HSK leads to a poorer visual outcome of amoebic treatment [20]. Clinicians should know the available laboratory test(s) and the relative advantages and disadvantages of the most commonly available laboratory techniques used in HSV diagnosis.

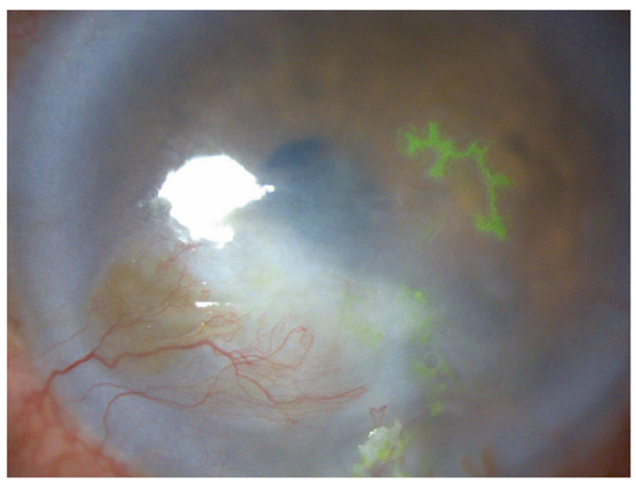

Fig. 1 Dendritic corneal ulceration in recurrent epithelial HSV. Fluorescein staining of an epithelial recurrence in a cornea with scarring and vascularisation resulting from multiple stromal recurrences.

\section{Identification of HSV DNA}

Polymerase chain reaction (PCR) identification of $\mathrm{HSV}$ DNA has a sensitivity of up to $100 \%$ [21] and has become the mainstay in laboratory confirmation of HSK. A further advantage of the method over others is the feasibility of detecting DNA of VZV and other viruses, acanthamoeba and other pathogens relevant to a case of keratitis with no prior confirmed HSV diagnosis. PCR testing of a sample is a diagnostic option in corneas with an epithelial defect and, with reduced sensitivity, in cornea excised at transplant surgery. One limitation of PCR is that its lack of usefulness in stromal as opposed to epithelial HSK. A further drawback is non-discriminative amplification of DNA in a sample, which does not help differentiate between active and latent infection and as a result has reduced specificity (71.4\%) [22]. More recently commercially available real-time PCR can provide a quantitative result with sensitivity and specificity comparable to conventional PCR [23, 24]. Real time or quantitative PCR has the advantage that, by calculating the amount of DNA present and the number of amplification cycles it has undergone, it can provide additional information on the amount of DNA present in the sample. Large amounts of DNA would be expected in an active infection and small amounts in inactive infection [25].

\section{Viral culture}

The gold standard for HSK diagnosis is virus culture. In addition to diagnosis, it allows viricidal drug sensitivity testing, strain identification and epidemiological tracing [26]. Virus isolation on culture has $100 \%$ specificity but low sensitivity [27]. After obtaining a sample it is required to be kept at $4{ }^{\circ} \mathrm{C}$ until plated on the cell monolayer, and isolation can take up to 10 days. Other than in reference laboratories and research settings, not least on account of expense, culture has become less widely available than PCR testing in hospital diagnostic laboratories.
Fig. 2 Geographic ulceration in recurrent epithelial HSV. Rose Bengal corneal staining in a patient with atopic

keratoconjunctivitis before (left) and following (right) treatment with topical ACV for 7 days.

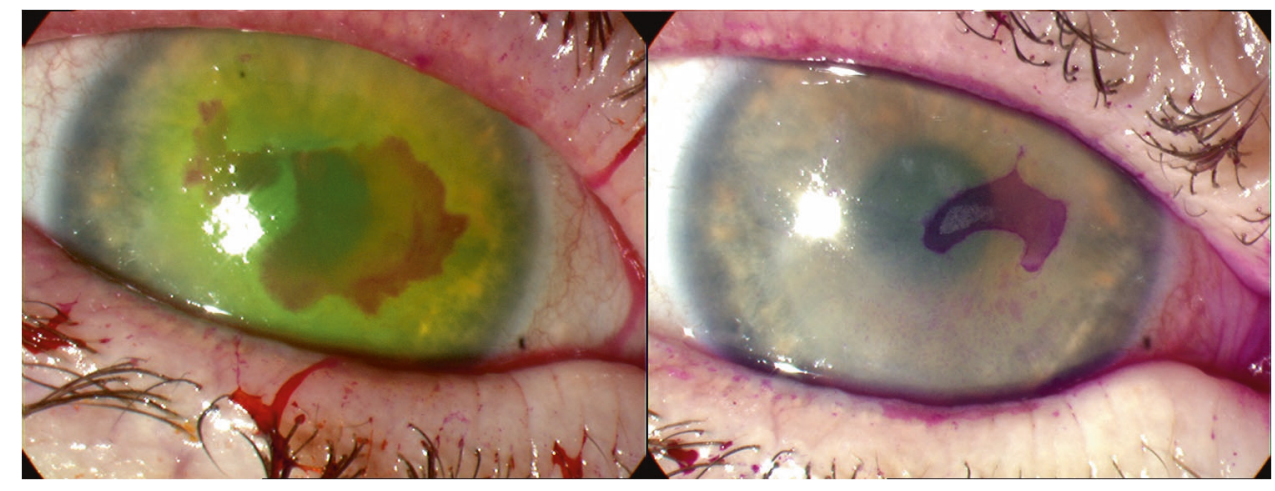




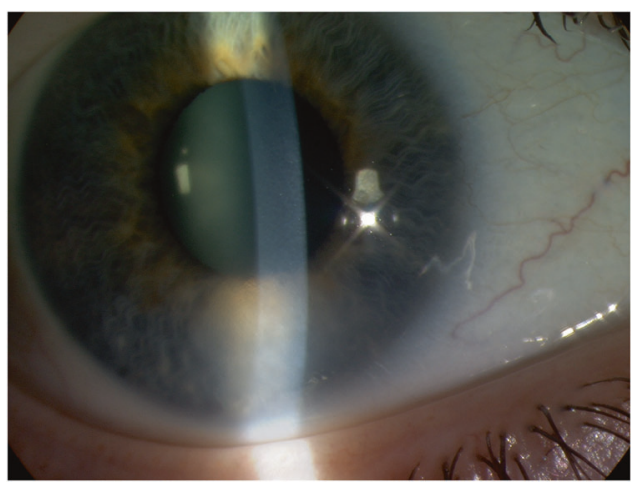

Fig. 3 Corneal oedema in HSV endotheliitis. The same diagnosis had been confirmed in the contralateral eye 5 years earlier.

\section{Immunohistochemistry identification of HSV antigens}

Fluorescence-based immunohistochemistry is not widely used but is a relatively fast method. Specificity is poorer than for PCR but sensitivity is as high as 80\% [22]. Fluorescein staining of the tear film must be avoided prior to sample collection as this can interfere with fluoresceinconjugated antibodies.

\section{Serology for antibodies against HSV}

Given the ubiquity of HSV infection and that HSK is not a primary infection but a reactivation of a latent infection, the detection of serum IgG or even IgM antibodies plays little role in diagnosis. The absence of $\mathrm{IgG}$ and IgM HSVspecific antibodies however can be helpful in excluding HSK, particularly in children or young adults who may not have been otherwise exposed to the virus. Individuals typically remain seropositive once infected with seroreversion rates of $\sim 1 \%$ and $5 \%$ over 15 years for HSV-1 and 2, respectively [28].

\section{Challenges in diagnosis}

A frequent diagnostic challenge in HSK is in investigating inactive disease, in particular determining if corneal scars are herpetic in origin. This is of importance in considering corneal transplantation and explaining the prognosis and implications of a HSV diagnosis to potential transplant recipients. Tissue obtained at the time of surgery or a corneal biopsy may enable a diagnosis. Remeijer et al. identified HSV-1 DNA by real-time PCR in $48 \%$ of keratoplasty specimens in patients with a history of HSK. Of interest, the corneal HSV DNA load quantified by real-time PCR correlated with increasing patient age and steroid use prior to transplant [25]. However, the longer the interval between the last active episode of HSK and the testing of the tissue sample the lower the chance viral DNA will be detected $[27,29]$ and the lower the viral load [25]. It is in these keratoplasty cases that the high sensitivity of PCR is more valuable than the high specificity of cell culture.

The sensitivity of PCR is especially helpful in investigating small volume aqueous humour samples in patients with suspected viral endotheliitis, in particular when associated with hypertensive uveitis (Fig. 3). Laboratory diagnosis of HSV can be essential in cases of hypertensive anterior uveitis and segmental iris atrophy without keratitis, not least to identify a specific treatment. In a series of 31 patients with suspected viral uveitis Van der Lelij et al. identified HSV DNA by PCR on aspirated aqueous humour in $83 \%$ of cases and VZV in $13 \%$ [30].

\section{Antiviral agents}

One of the favourable aspects of HSK is that the available antiviral agents are effective and well tolerated. This section briefly explains the replication cycle of HSV and the treatment targets followed by a review of the classes of drug available.

HSV 1 is a double stranded DNA virus that expresses four vital glycoproteins ( $\mathrm{gB}, \mathrm{gD}, \mathrm{gH}$ and $\mathrm{gL}$ ) and an additional two ( $\mathrm{gC}$ and $\mathrm{gK}$ ) that regulate viral entry and membrane fusion respectively [31, 32]. Once the nucleocapsid enters the hosts cell it translocates to the host nucleus where the viral genome enters the nucleus through a nuclear pore [33]. The HSV 1 transcript contains three kinetic classes of gene; and successful replication of all three is required for HSV-1 protein synthesis and replication [33]. Once the replicated genome and nucleocapsid are assembled in the host nucleus the completion of the HSV 1 virus is completed in the cytoplasm of the host cell including the viral envelope. The virus then migrates from the host cell exploiting host enzymes heparanase and cathepsin [34, 35]. Due to the complex nature of HSV replication there are numerous targets for pharmacological intervention.

\section{Nucleoside analogues: mechanism of pharmacological activity and limitations}

Aciclovir (ACV) and other nucleoside analogues, in particular ganciclovir (GCV) and trifluorothymidine, are currently the main topical treatments for HSV infections. ACV was the first introduced and remains most widely used. It is a prodrug that, once entering the host cell, is phosphorylated by the HSV protein thymidine kinase (TK), before being twice more phosphorylated by host enzymes to its active 
form ACV triphosphate [36]. This active form competes with deoxyguanosine trisphosphate to be incorporated into the replicating viral genome causing premature termination [37]. ACV is by this mechanism an effective treatment for HSV infection, widely available as an oral, intravenous and topical formulation. ACV has good oral bioavailability although absorption decreases with increasing dose, i.e. $20 \%$ of $200 \mathrm{mg}$ and $12 \%$ of $800 \mathrm{mg}$ due to absorption saturation; intravenous compared to oral ACV has around eight times higher bioavailability [38]. Oral ACV absorption can be increased by the addition a valine moiety in the form of valaciclovir. Consequently, oral valaciclovir can achieve comparable bioavailability to intravenous ACV [39]. ACV has a favourable side effect profile as it requires the viral TK to initiate conversion to its active form, implying that its inhibitory effects are only seen at a significant level in infected cells [40]. ACV and its metabolites are excreted renally and dose adjustment is required in renal failure and monitoring of renal function in long term ACV use [41]. Aciclovir and nucleoside analogues do have three main weaknesses; firstly, viral drug resistance is an emerging issue, particularly in immunocompromised patients [42]. Drug resistance is usually the result of a virus strain that either does not produce TK, or produces a variant that does not metabolise ACV [43]. Secondly as they block viral replication they are not directly active against viral proteins. Finally, and of most importance in keratitis management, they are not effective in elimination of latent HSV infection.

\section{Foscarnet}

The pyrophosphate analogue DNA polymerase inhibitor foscarnet is an active drug that is used in HSV and cytomegalovirus infections. Unlike nucleoside analogues it is not metabolised by viral TK and for this reason is effective in cases of ACV resistance, administered topically in keratitis. In spite of this, resistance to foscarnet has been documented, caused by mutations in the viral DNA polymerase gene which decrease its inhibitory effect [44].

\section{Helicase-primase inhibitors}

Helicase-primase inhibitors (pritelivir and amenamevir) are a novel class of antiviral medication, that prevents viral DNA synthesis independent of TK. Amenamevir exhibits anti-herpes-zoster and simplex activity and has been licenced for the treatment of shingles in Japan as it demonstrated non-inferiority over Valaciclovir [45]. Pritelivir has anti-HSV activity with clinical trials on its role in the management of genital herpes [46]. Their role in the management of HSK remains unknown at present but will be an area of research interest in the future.

\section{Epithelial keratitis management problems}

Epithelial keratitis should in all cases have resolved within 2 or at most 3 weeks on topical antiviral taken five times daily. Indeed, the natural history of epithelial keratitis is of a self-resolving condition lasting up to 2 weeks $[47,48]$. The aim of treatment is to reduce the pain and the disease duration. There is no evidence of differences in effectiveness of topical antiviral treatments and ACV, GCV and trifluorothymidine and are all relatively well tolerated [49]. The same meta-analysis concluded that a combination of mechanical debridement and antiviral therapy might allow faster healing but firm conclusions were limited by heterogeneity among studies.

\section{Unresponsive epithelial keratitis}

In cases of epithelial HSK unresponsive to treatment, laboratory investigation for persisting virus is essential, either by PCR or culture. This provides key primary information in guiding management: a suggested algorithm for further intervention is shown in Fig. 4. Poor compliance with five times daily topical antiviral is probably the commonest underlying reason for persisting ulceration. In adults compliant with treatment there is no additional benefit from oral antiviral therapy. Oral ACV is effective in the treatment of epithelial HSK [50] but an alternative to topical administration. In children and adults with learning disability oral administration can be a useful treatment, particularly when regular application of topical therapy is difficult [51]. Antiviral resistance, discussed below, is a relatively rare cause for persistent ulceration, at least in immunocompetent patients. Persisting ulceration may be accompanied by unrecognised subjacent stromal inflammation. This is identified by slit-lamp examination and its management requires the addition of topical steroid (see below).

A further cause of persisting ulceration is metaherpetic keratitis (a variant of neurotrophic keratitis), characterised by absence of active viral infection and it follows a dendritic or geographic ulcer. The causes of metaherpetic keratitis are numerous including loss of superficial corneal innervation, unstable tear film and toxicity from topical antivirals and preservatives. Management requires close supervision over several weeks and should commence with discontinuation of non-essential topical medications. Additional nonspecific measures to support corneal re-epithelialisation include lubricants and botulinum toxin-induced therapeutic ptosis or temporary tarsorrhaphy. Further interventions used in cases with significant corneal anaesthesia include conjunctival flaps [52], amniotic membrane [52], topical autologous serum [53] or topical recombinant human nerve growth factor [54]. 


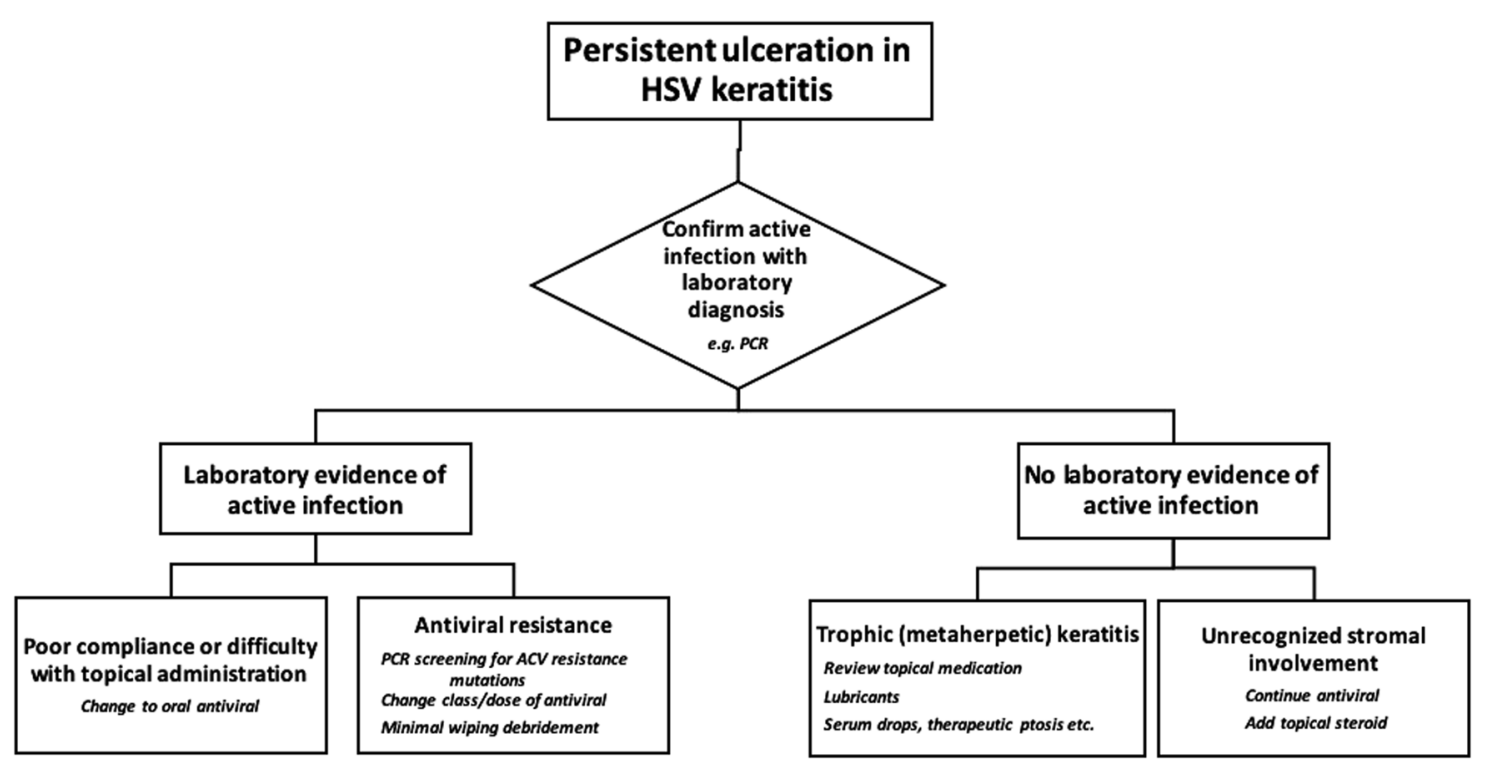

Fig. 4 Management of persistent ulceration in HSV keratitis. Laboratory confirmation or exclusion of active viral infection is critical in this suggested approach in the management of persistent corneal ulceration.

\section{Aciclovir resistance}

Although ACV has become very widely used in eye and other HSV infections, the prevalence of HSV-1 resistance has remained very low in immunocompetent hosts. It is significantly more prevalent in the immunocompromised, including atopic patients. Resistance in most cases results from mutations in the virus TK gene, resulting in a defective TK protein. Duan et al. reported 6.4\% prevalence of ACVresistant corneal isolates in immunocompetent HSK patients, which correlated with specific TK polymorphisms and poor response in vivo to ACV [55]. Clinicians managing patients with persistent ulceration due to suspected antiviral resistance should check local virology laboratory investigative facilities. The Public Health England virology laboratory (info@PHE.gov.uk) at present offers twofold investigation, requiring two corneal samples. First, viral DNA can be examined by PCR for known mutation sequences in TK and DNA polymerase genes. Second, isolation of virus in culture enables quantification of in vitro viricidal activity against the isolate of a range of drugs, which allows rationalised drug selection and possibly a TKindependent drug such as foscarnet. The work of Duan et al. has demonstrated that the proportion of ACV-resistant virus particles in cornea determines the efficacy of ACV [42, 55]. Accordingly, if an epithelial lesion has not healed within 2 weeks in a compliant patient and persistent HSV DNA is identified, options are either ACV at increased dose $800 \mathrm{mg}$ 5 times/day (alternatively valaciclovir $1 \mathrm{~g}$ 3/day) for 1 week, or foscarnet $2.6 \mathrm{mg} / \mathrm{ml}$ drops two hourly for 2 weeks.

In conclusion epithelial HSK is a self-limiting condition that can be shortened with topical antiviral therapy. In cases of poor treatment response, laboratory confirmation of diagnosis is essential. Further strategies such as changing to oral antiviral to improve compliance and debridement of lesions can be considered.

\section{Stromal keratitis management problems}

Stromal differs from epithelial keratitis in that there is both a local viral cytopathic effect and a host immunological and reparative response [56]. The Herpetic Eye Disease Study (HEDS) group reported a series of placebo-controlled randomised controlled trials that has been pivotal in guiding the treatment and prevention of stromal keratitis and its recurrence. Findings demonstrated clear benefit of topical corticosteroid [57] in one study in which participants were treated with trifluorothymidine plus either 10-week tapering topical prednisolone or placebo. However, despite the significant benefit in the steroid-treated group, it was found in this group that half of the failures occurred within 6 weeks of completing steroid treatment. This observation makes the point that steroid drops should be reduced cautiously and possibly continued at very low frequency and potency for months after stromal keratitis symptom resolution. A further observation of interest in this trial is that there was no difference in the visual acuity at 6 months between the groups, suggesting that delaying the initiation of steroid treatment does not have a long-term effect adverse visual consequence. Initial treatment of stromal keratitis with antiviral only may have a helpful effect in reducing stromal virus load, but there is no controlled trial of antiviral with delayed steroid which has examined for any benefit in reduced recurrence rate. 


\section{Complex stromal keratitis management}

One of the more troublesome complications of HSK management is concurrent raised intraocular pressure, most frequently as an adverse effect of topical steroids. There are small uncontrolled studies of topical cyclosporin, a calcineurin inhibitor, reporting benefit in non-necrotising stromal keratitis and reducing the required dose of steroid $[58,59]$. HSV stromal keratitis associated with endotheliitis and/or uveitis is less common and requires treatment with a combination of topical steroid with both oral and topical antiviral. For highest intraocular steroid concentrations, the steroid in keratouveitis needs to be prednisolone acetate $1 \%$ (L Remeijer, personal communication), gradually reducing to less potent steroids. In these cases, ACV is needed at $800 \mathrm{mg}$ five times/day to reach the high aqueous humour levels necessary in addition to topical ACV [60].

\section{Management of stromal vascularisation}

Stromal vascularisation, and associated lymphangiogenesis, complicates active and inactive HSK through loss of corneal transparency, lipid keratopathy and an increased risk of subsequent keratoplasty rejection and failure. The treatment of corneal vascularisation has been challenging, not least as slit-lamp examination underestimates the degree and extent of corneal vascularisation compared to multimodal imaging using fluorescein and indocyanine green angiography [61]. Following a trial of topical corticosteroid, that has a broad spectrum of angiogenic effects [62], accurate imaging is recommended prior to any invasive treatments. Angiography guided fine needle diathermy of afferent feeder vessels is highly effective when a single or few feeder vessels are identified, with the majority of patients requiring less than three treatments [63].

Multiple, diffuse afferent vessels provide more of a treatment challenge where a combination of treatments is often required. Anti-vascular endothelial growth factor (anti-VEGF) agents have not been as effective for corneal vascularisation compared to choroidal neovascularisation. Off licence use of Anti-VEGF agents have had varying success either given subconjunctivally near the area of maximal vascularisation or topically $[64,65]$. The main limitations being the inability to penetrate the corneal epithelium and remove already established vessels. A Pilot study of combined fine needle diathermy and topical bevacizumab reduced the extent of vascularisation but provided no improvement in visual acuity [66]. Aganirsen, an antisense oligonucleotide inhibiting insulin receptor substrate-1 expression, induces significant reduction in corneal vascularisation and improvements in patient reported quality of life although no significant increase in visual acuity [67].

\section{Prevention of stromal keratitis recurrence}

Recurrent stromal HSK is the main cause of visual loss from HSK [5]. To preserve visual acuity, rapid resolution of active infections and prevention of recurrence is essential. The HEDS group [68] investigated the rate of recurrence in 703 patients, of whom 337 had prior stromal HSK, randomised to placebo or $400 \mathrm{mg}$ ACV twice a day for 1 year and followed for a further 6 months. Overall risk of recurrence of either epithelial or stromal keratitis was reduced by $45 \%$; cumulative probability of stromal recurrence was $14 \%$ in the ACV and $28 \%$ in the placebo groups. Notwithstanding the reduction in recurrence risk to $14 \%$ rather than zero and within a follow-up duration of only 6 months, the reduction by $50 \%$ in patients with stromal HSK is clinically significant and justifies this regime in selected patients. Clinicians must on a case-by-case basis select candidate patients based on frequency of recurrences but also visionthreatening stromal opacity. Questions arise on whether a higher ACV dose or longer duration prophylaxis regime would further reduce stromal recurrence risk. These may be worth analysis in subsequent trials. However, one must bear in mind the possibility that prophylaxis increases risk of ACV-resistant keratitis caused by selection for corneal ACV-resistant HSV-1 viruses. Van Velzen et al. reported an increased odds ratio of 3.42 of developing resistant strains of HSV if patients have been on ACV for over a year [69]. This was also associated with increased risk of prolonged recurrence duration suggestive of treatment failure. Taken together these studies suggest in addition to case selection, that ACV prophylaxis be considered for one year only and subsequent recurrences be treated aggressively with monitoring for ACV-resistant strains.

Acknowledgements DFPL was supported in part by the National Institute for Health Research Moorfields Biomedical Research Centre and the NIHR Moorfields Clinical Research Facility, London, United Kingdom.

\section{Compliance with ethical standards}

Conflict of interest The authors declare that they have no conflict of interest.

Publisher's note Springer Nature remains neutral with regard to jurisdictional claims in published maps and institutional affiliations.

\section{References}

1. Looker KJ, Magaret AS, May MT, Turner KM, Vickerman P, Gottlieb SL, et al. Global and regional estimates of prevalent and incident herpes simplex virus type 1 Infections in 2012. PLoS ONE 2015;10:e0140765. 
2. Looker KJ, Magaret AS, Turner KM, Vickerman P, Gottlieb SL, Newman LM. Global estimates of prevalent and incident herpes simplex virus type 2 infections in 2012. PLoS ONE 2015;10: e114989.

3. Liesegang TJ. Herpes simplex virus epidemiology and ocular importance. Cornea 2001;20:1-13.

4. Labetoulle M, Auquier P, Conrad H, Crochard A, Daniloski M, Bouee $\mathrm{S}$, et al. Incidence of herpes simplex virus keratitis in France. Ophthalmology 2005;112:888-95.

5. Young RC, Hodge DO, Liesegang TJ, Baratz KH. Incidence, recurrence, and outcomes of herpes simplex virus eye disease in Olmsted County, Minnesota, 1976-2007: the effect of oral antiviral prophylaxis. Arch Ophthalmol. 2010;128:1178-83.

6. Akhtar J, Tiwari V, Oh MJ, Kovacs M, Jani A, Kovacs SK, et al. HVEM and nectin-1 are the major mediators of herpes simplex virus 1 (HSV-1) entry into human conjunctival epithelium. Investig Ophthalmol Vis Sci. 2008;49:4026-35.

7. Bertke AS, Patel A, Krause PR. Herpes simplex virus latencyassociated transcript sequence downstream of the promoter influences type-specific reactivation and viral neurotropism. J Virol. 2007;81:6605-13.

8. Branco FJ, Fraser NW. Herpes simplex virus type 1 latencyassociated transcript expression protects trigeminal ganglion neurons from apoptosis. J Virol. 2005;79:9019-25.

9. Wishart MS, Darougar S, Viswalingam ND. Recurrent herpes simplex virus ocular infection: epidemiological and clinical features. Br J Ophthalmol. 1987;71:669-72.

10. Kaswin G, Rousseau A, M'Garrech M, Barreau E, Pogorzalek N, De Monchy I, et al. Optical aberrations in patients with recurrent herpes simplex keratitis and apparently normal vision. $\mathrm{Br} \mathrm{J}$ Ophthalmol. 2013;97:1113-7.

11. Souza PM, Holland EJ, Huang AJ. Bilateral herpetic keratoconjunctivitis. Ophthalmology 2003;110:493-6.

12. Chong EM, Wilhelmus KR, Matoba AY, Jones DB, Coats DK, Paysse EA. Herpes simplex virus keratitis in children. Am J Ophthalmol. 2004;138:474-5.

13. Reynaud C, Rousseau A, Kaswin G, M'garrech M, Barreau E, Labetoulle M. Persistent impairment of quality of life in patients with herpes simplex keratitis. Ophthalmology 2017;124:160-9.

14. Lairson DR, Begley CE, Reynolds TF, Wilhelmus KR. Prevention of herpes simplex virus eye disease: a cost-effectiveness analysis. Arch Ophthalmol. 2003;121:108-12.

15. Bierly JR, Ostler HB. Varicella dendritic keratitis. J Pediatr Ophthalmol Strabismus. 1994;31:53-6.

16. Hu AY, Strauss EC, Holland GN, Chan MF, Yu F, Margolis TP. Late varicella-zoster virus dendriform keratitis in patients with histories of herpes zoster ophthalmicus. Am J Ophthalmol. 2010;149:214-20.

17. Wilhelmus KR, Dawson CR, Barron BA, Bacchetti P, Gee L, Jones DB, et al. Risk factors for herpes simplex virus epithelial keratitis recurring during treatment of stromal keratitis or iridocyclitis. Herpetic Eye Disease Study Group. Br J Ophthalmol. 1996;80:969-72.

18. Pflugfelder SC, Huang A, Crouse C. Epstein-Barr virus keratitis after a chemical facial peel. Am J Ophthalmol. 1990;110:571-3.

19. Okuno T, Hooper LC, Ursea R, Smith J, Nussenblatt R, Hooks JJ, et al. Role of human herpes virus 6 in corneal inflammation alone or with human herpesviruses. Cornea 2011;30:204-7.

20. Robaei D, Carnt N, Minassian DC, Dart JK. The impact of topical corticosteroid use before diagnosis on the outcome of Acanthamoeba keratitis. Ophthalmology 2014;121:1383-8.

21. Subhan S, Jose RJ, Duggirala A, Hari R, Krishna P, Reddy S, et al. Diagnosis of herpes simplex virus-1 keratitis: comparison of Giemsa stain, immunofluorescence assay and polymerase chain reaction. Curr Eye Res. 2004;29:209-13.
22. El-Aal AM, El Sayed M, Mohammed E, Ahmed M, Fathy M. Evaluation of herpes simplex detection in corneal scrapings by three molecular methods. Curr Microbiol. 2006;52:379-82.

23. Köller T, Kurze D, Lange M, Scherdin M, Podbielski A, Warnke P. Implementation and evaluation of a fully automated multiplex real-time PCR assay on the BD max platform to detect and differentiate herpesviridae from cerebrospinal fluids. PLoS ONE 2016;11:e0153991.

24. Mengelle C, Sandres-Sauné K, Miédougé M, Mansuy JM, Bouquies $\mathrm{C}$, Izopet J. Use of two real-time polymerase chain reactions (PCRs) to detect herpes simplex type 1 and 2-DNA after automated extraction of nucleic acid. J Med Virol. 2004;74:459-62.

25. Remeijer L, Duan R, van Dun JM, Wefers Bettink MA, Osterhaus $\mathrm{AD}$, Verjans GM. Prevalence and clinical consequences of herpes simplex virus type 1 DNA in human cornea tissues. J Infect Dis. 2009;200:11-9.

26. Athmanathan S, Reddy SB, Nutheti R, Rao GN. Comparison of an immortalized human corneal epithelial cell line with Vero cells in the isolation of Herpes simplex virus-1 for the laboratory diagnosis of Herpes simplex keratitis. BMC Ophthalmol. 2002;2:3.

27. Kaye SB, Baker K, Bonshek R, Maseruka H, Grinfeld E, Tullo A, et al. Human herpesviruses in the cornea. $\mathrm{Br} \mathrm{J}$ Ophthalmol. 2000;84:563-71.

28. Rubicz R, Zhu J, Laston S, Cole SA, Voruganti VS, Ebbesson SOE, et al. Statistical genetic analysis of serological measures of common, chronic infections in Alaska Native participants in the GOCADAN study. Genet Epidemiol. 2013;37:751-7.

29. O'Brien WJ, Tsao LS, Taylor JL. Tissue-specific accumulation of latency-associated transcripts in herpes virus-infected rabbits. Investig Ophthalmol Vis Sci. 1998;39:1847-53.

30. Van der Lelij A, Ooijman FM, Kijlstra A, Rothova A. Anterior uveitis with sectoral iris atrophy in the absence of keratitis: a distinct clinical entity among herpetic eye diseases. Ophthalmology 2000;107:1164-70.

31. Farooq AV, Valyi-Nagy T, Shukla D. Mediators and mechanisms of herpes simplex virus entry into ocular cells. Curr Eye Res. 2010;35:445-50.

32. Spear PG. Herpes simplex virus: receptors and ligands for cell entry. Cell Microbiol. 2004;6:401-10.

33. Kukhanova MK, Korovina AN, Kochetkov SN. Human herpes simplex virus: life cycle and development of inhibitors. Biochem (Mosc). 2014;79:1635-52.

34. Hadigal SR, Agelidis AM, Karasneh GA, Antoine TE, Yakoub AM, Ramani VC, et al. Heparanase is a host enzyme required for herpes simplex virus-1 release from cells. Nat Commun. 2015;6:6985.

35. Hopkins J, Yadavalli T, Agelidis AM, Shukla D. Host enzymes heparanase and cathepsin 1 promote herpes simplex virus 2 release from cells. J Virol. 2018;92:pii: e01179-18.

36. Gnann JW Jr, Barton NH, Whitley RJ. Acyclovir: mechanism of action, pharmacokinetics, safety and clinical applications. Pharmacotherapy. 1983;3:275-83.

37. Whitley RJ, Gnann JW Jr. Acyclovir: a decade later. N Engl J Med. 1992;327:782-9.

38. Kaye S, Choudhary A. Herpes simplex keratitis. Prog Retin Eye Res. 2006;25:355-80.

39. MacDougall C, Guglielmo BJ. Pharmacokinetics of valaciclovir. J Antimicrob Chemother. 2004;53:899-901.

40. Fyfe JA, Keller PM, Furman PA, Miller RL, Elion GB. Thymidine kinase from herpes simplex virus phosphorylates the new antiviral compound, 9-(2-hydroxyethoxymethyl) guanine. J Biol Chem. 1978;253:8721-7.

41. Becker BN, Fall P, Hall C, Milam D, Leonard J, Glick A, et al. Rapidly progressive acute renal failure due to acyclovir: case report and review of the literature. Am J Kidney Dis. 1993;22:611-5. 
42. Duan R, de Vries RD, van Dun JM, van Loenen FB, Osterhaus $\mathrm{AD}$, Remeijer L, et al. Acyclovir susceptibility and genetic characteristics of sequential herpes simplex virus type 1 corneal isolates from patients with recurrent herpetic keratitis. J Infect Dis. 2009;200:1402-14.

43. Larder BA, Cheng YC, Darby G. Characterization of abnormal thymidine kinases induced by drug-resistant strains of herpes simplex virus type 1. J Gen Virol. 1983;64:523-32.

44. Bonnafous P, Naesens L, Petrella S, Gautheret-Dejean A, Boutolleau D, Sougakoff W, et al. Different mutations in the HHV-6 DNA polymerase gene accounting for resistance to foscarnet. Antivir Ther. 2007;12:877-88.

45. Kawashima M, Nemoto O, Honda M, Watanabe D, Nakayama J, Imafuku S, et al. Amenamevir, a novel helicase-primase inhibitor, for treatment of herpes zoster: a randomized, double-blind, valaciclovir-controlled phase 3 study. J Dermatol. 2017;44:1219-27.

46. Wald A, Corey L, Timmler B, Magaret A, Warren T, Tyring S, et al. Helicase-primase Inhibitor Pritelivir for HSV-2 Infection. $\mathrm{N}$ Engl J Med. 2014;370:201-10.

47. Thygeson P. Historical observations on herpetic keratitis. Surv Ophthalmol. 1976;21:82-90.

48. Liesegang TJ. Epidemiology of ocular herpes simplex. Natural history in Rochester, Minn, 1950 through 1982. Arch Ophthalmol. 1989;107:1160-5.

49. Wilhelmus KR. Antiviral treatment and other therapeutic interventions for herpes simplex virus epithelial keratitis. Cochrane Database Syst Rev. 2015;1:CD002898.

50. Collum LM, McGettrick P, Akhtar J, Lavin J, Rees PJ. Oral acyclovir (Zovirax) in herpes simplex dendritic corneal ulceration. Br J Ophthalmol. 1986;70:435-8.

51. Schwartz GS, Holland EJ. Oral acyclovir for the management of herpes simplex virus keratitis in children. Ophthalmology 2000;107:278-82.

52. Dua HS, Said DG, Messmer EM, Rolando M, Benitez-DelCastillo JM, Hossain PN, et al. Neurotrophic Keratopathy. Prog Retin Eye Res. 2018;66:107-31.

53. Jeng BH, Dupps WJ Jr. Autologous serum 50\% eyedrops in the treatment of persistent corneal epithelial defects. Cornea 2009;28:1104-8.

54. Pflugfelder SC, Massaro-Giordano M, Perez VL, Hamrah P, Deng SX, Espandar L, et al. Topical recombinant human nerve growth factor (Cenegermin) for neurotrophic keratopathy: a multicenter randomized vehicle-controlled pivotal trial. Ophthalmology 2020;127:14-26.

55. Duan R, de Vries RD, Osterhaus AD, Remeijer L, Verjans GM. Acyclovir-resistant corneal HSV-1 isolates from patients with herpetic keratitis. J Infect Dis. 2008;198:659-63.

56. Hillenaar T, van Cleynenbreugel H, Verjans GM, Wubbels RJ, Remeijer L. Monitoring the inflammatory process in herpetic stromal keratitis: the role of in vivo confocal microscopy. Ophthalmology 2012;119:1102-10.

57. Wilhelmus KR, Gee L, Hauck WW, Kurinij N, Dawson CR, Jones DB, et al. Herpetic eye disease study. a controlled trial of topical corticosteroids for herpes simplex stromal keratitis. Ophthalmology 1994;101:1883-95.

58. Heiligenhaus A, Steuhl KP. Treatment of HSV-1 stromal keratitis with topical cyclosporin A: a pilot study. Graefes Arch Clin Exp Ophthalmol. 1999;237:435-8.

59. Rao SN. Treatment of herpes simplex virus stromal keratitis unresponsive to topical prednisolone $1 \%$ with topical cyclosporine 0.05\%. Am J Ophthalmol. 2006;141:771-2.

60. Hung SO, Patterson A, Rees PJ. Pharmacokinetics of oral acyclovir (Zovirax) in the eye. Br J Ophthalmol. 1984;68:192-5.

61. Anijeet DR, Zheng Y, Tey A, Hodson M, Sueke H, Kaye SB. Imaging and evaluation of corneal vascularization using fluorescein and indocyanine green angiography. Investig Ophthalmol Vis Sci. 2012;53:650-8.

62. Maddula S, Davis DK, Maddula S, Burrow MK, Ambati BK. Horizons in therapy for corneal angiogenesis. Ophthalmology 2011;118:591-9.

63. Spiteri N, Romano V, Zheng Y, Yadav S, Dwivedi R, Chen J, et al. Corneal angiography for guiding and evaluating fine-needle diathermy treatment of corneal neovascularization. Ophthalmology 2015;122:1079-84.

64. Petsoglou C, Balaggan KS, Dart JK, Bunce C, Xinget W, Ali RR, et al. Subconjunctival bevacizumab induces regression of corneal neovascularisation: a pilot randomised placebo-controlled doublemasked trial. Br J Ophthalmol. 2013;97:28-32.

65. Cheng SF, Dastjerdi MH, Ferrari G, Okanobo A, Bower KS, Ryan DS, et al. Short-term topical bevacizumab in the treatment of stable corneal neovascularization. Am J Ophthalmol. 2012;154:940-948.e1.

66. Koenig Y, Bock F, Kruse FE, Stock K, Cursiefen C. Angioregressive pretreatment of mature corneal blood vessels before keratoplasty: fine-needle vessel coagulation combined with antiVEGFs. Cornea 2012;31:887-92.

67. Cursiefen C, Viaud E, Bock F, Geudelin B, Ferry A, Kadlecova P, et al. Aganirsen antisense oligonucleotide eye drops inhibit keratitis-induced corneal neovascularization and reduce need for transplantation: the I-CAN study. Ophthalmology 2014;121:1683-92.

68. Herpetic Eye Disease Study Group. Acyclovir for the prevention of recurrent herpes simplex virus eye disease. $\mathrm{N}$ Engl J Med. 1998;339:300-6.

69. van Velzen M, van de Vijver DA, van Loenen FB, Osterhaus AD, Remeijer L. Acyclovir prophylaxis predisposes to antiviralresistant recurrent herpetic keratitis. J Infect Dis. 2013;208: $1359-65$ 